\title{
Reducing emissions of the fast growing Vietnamese coal sector: the chances offered by biomass co-firing
}

\author{
An Ha Truong ${ }^{a, c, *}$, Piera Patriziob, Sylvain Leduc ${ }^{b}$, Florian Kraxner ${ }^{b}$, \\ Minh Ha-Duong a,d
}

a) Clean Energy and Sustainable Development Laboratory (CleanED), University of Science and Technology of Hanoi (USTH), 18 Hoang Quoc Viet St, Hanoi, Vietnam

b) Ecosystems Services and Management (ESM), International Institute for Applied Systems Analysis (IIASA), Schlossplatz 1 - A-2361 Laxenburg, Austria

c) Centre for Research and Technology Transfer, Vietnam Academy of Science and Technology, 18 Hoang Quoc Viet St, Hanoi, Vietnam

d) Centre International de Recherche sur l'Environnement et le Développement, Campus du Jardin Tropical, 45 bis, Avenue de la Belle Gabrielle, 94736 Nogent-sur-Marne Cedex, France

* Corresponding author. Email: truonganha87@gmail.com

\section{Sep 07, 2018}

\begin{abstract}
Vietnam's Power Development Plan 7A authorized many new coal power plants projects, implying an increase of greenhouse gases emissions from $90 \mathrm{MtCO}_{2} \mathrm{eq} / \mathrm{year}$ today to $360 \mathrm{MtCO}_{2}$ eq/year in 2030. How could co-firing technology -that is the partial substitution of coal by biomass- contributes to mitigate that problem? In this study, we assess the costs and potentials of co-firing rice residues in present and planned coal power plants in Vietnam using a spatially explicit optimization model: BeWhere, adapted as recursive annual dynamic. We found that, the cost of $\mathrm{CO}_{2}$ emissions is the key parameter determining at what level the technology is used. A cost of $\mathrm{CO}_{2}$ emissions of $8 \$ / \mathrm{tCO}_{2}$ mobilizes the maximum technical potential of the rice straw and husk domestic resource, with an annual emission reduction of $28 \mathrm{MtCO}_{2} \mathrm{eq} / \mathrm{year}$ by 2030 . At this level, biomass co-firing contributes to an $8 \%$ emission reduction in the coal power sector with the abatement cost of 137 Million USD.
\end{abstract}

Keywords: Co-firing, emission reduction, bioenergy, rice residues, greenhouse gas emissions, spatial explicit exploration;

\section{Highlights}

- Vietnam can reduce $\mathrm{CO}_{2}$ emissions from coal power plants by co-firing rice residues.

- The maximum technical potential is an 8\% reduction compared to Business As Usual.

- Co-firing viability require carbon credits or a renewable portfolio standard. 


\section{Introduction}

In 2018 , coal contributes for about $40 \%$ of world's electricity production. However, global trend of coal power plant development is going downhill with decline of $0.6 \%$ for 2014 and $2.8 \%$ for 2015 [1]. This trend reflects the rise of renewable energy in global energy agenda, not only because of the climate goals set by almost all nations in Paris Agreement but also because of the increasing competitiveness of renewable energy technologies. Vietnam committed to reduce its emissions by $8 \%$ in 2030 compared to Business As Usual (BAU) and up to $25 \%$ with international support as its Nationally Determined Contribution (NDC) [2]. The emission projection in Vietnam's NDC is $784 \mathrm{MtCO}_{2}$ eq in 2030 in BAU scenario. The Vietnam Green Growth Strategy also set target for energy activities to reduce GHG emission by $20 \%$ to $30 \%$ by 2030 compared to BAU. These ambitions show the willingness of the Vietnamese government to fight climate change. Nevertheless, these ambitions are not compatible with the vision of National Power Development Plan (PDP7A) approved by the Government in 2016.

In 2017, twenty coal power plants were in operation in Vietnam with a total installed capacity of $13 \mathrm{GW}$ [3]. Together they provided 33.5\% of total electricity supply [4]. By 2030, the current PDP 7A authorizes to add $43 \mathrm{GW}$ of coal-based generation capacity [5]. According to this plan, new coal power plants are set to open every year from 2018 until 2030. More than $50 \%$ of total electricity production could come from coal-fired stations by 2030. The main argument for increasing coal in power mix is to meet the power demand of a fast-growing economy at a reasonable price.

During the past decade, Vietnam has experienced the highest increase of greenhouse gas emission among Association of South East Asian Nations (ASEAN) countries: total GHG emission and emission per capita increased three folds in ten years while carbon intensity over GDP increased by 48\% [3]. The Initial Biennial Updated Report of Vietnam to UNFCCC [6] projects that the GHG emissions of the energy sector will rise from $141 \mathrm{MtCO}_{2} \mathrm{eq}$ in 2010 to $381 \mathrm{MtCO}_{2}$ eq in 2020 and to $648 \mathrm{MtCO}_{2}$ eq in 2030. This sector accounts for more than $85 \%$ of total national GHG emissions. In 2014, total emissions of all operating coal-based power plants in Vietnam is estimated at $36.8 \mathrm{Mt}$ [7]. With the increase of coal capacity, GHG emissions from coal power sector is estimated at 176.9 Mt in 2020 and 490.6 Mt in 2030 [7], which is an order of magnitude higher than the 2014 level.

Setting a national emission reduction target at $25 \%$ in a context where the planned emissions from coal increase ten times raises a tough challenge. These coal emissions account for $63 \%$ total national GHG emissions in BAU scenario in 2030. This issue of balancing between electricity supply and climate change goal is under the umbrella of well-known energy trilemma concept, which defined by the World Energy Council [8] as "the conflicting goals that governments face in securing energy supplies, providing universal energy access and promoting environmental protection". Therefore, it is urgent to assess all kind of technologies that could help Vietnam to harmonize the emission target with the power development plan and work towards the sustainable development of the country.

Biomass co-firing has long been recognized as a way to reduce the greenhouse gas emission from coal burning power plants [9-12] and as the most cost-effective approach to biomass utilization by the electric utility industry [9-12]. Co-firing can utilize the existing coal power plants equipment, such as boilers and fuel feeding chains. This makes investment costs for cofiring the lowest among biomass power technologies [16]. Moreover, co-firing has higher conversion efficiency than dedicated biomass-only power plants. Efficiency of biomass combustion to electricity in co-firing plants could be $33 \%-45 \%[9,10,17]$, depending on plant size, technology and biomass share and quality, while it is only about $30 \%$ in dedicated biomass power plant [17]. With all these advantages, co-firing is an attractive option in Vietnam where coal-based electricity generation expands rapidly and a large biomass resource base is available. 
Co-firing is a mature technology and has been applied at industrial scale in many countries $[10,18]$. The technology, however, is yet to be used much in Vietnam. The PDP 7A mentions co-firing biomass with coal but does not state clearly the roadmap to develop co-firing technology in the country. Aware of domestic coal shortage in near future, the government has funded a research project in pilot scale to mix imported coal with domestic coal in a coal power plant [19]. Nevertheless, there is a lack of local expertise on co-firing biomass with coal. To this end, the aim of our study is to explore quantified scenarios for implementing co-firing at the national scale, considering the cost and greenhouse gas mitigation. To our best knowledge, this study is the first attempt to evaluate co-firing in Vietnam at national scale.

Studies show that co-firing using domestic biomass resources provide a better results in emission reduction compared to using imported resources [12,20]. As Vietnam has substantial biomass potential, in this study we look only at domestic biomass resource as co-firing fuel. An estimation by [21] shows that total solid biomass fuel potential in Vietnam by 2010 was $1346 \mathrm{PJ}$, about half of total energy consumption of the country in 2009. According to this estimation, agriculture produced almost $70 \%$ of the total solid biomass fuel potential and the rest came from firewood and wood residue. Rice residues (straw and husk) have the largest potential among agricultural residues which account for $30 \%$ of total solid biomass potential in term of energy. Rice is the most important crop with annual production in 2016 of $44 \mathrm{Mt}$ [22]. For $1 \mathrm{t}$ of rice produced, there will be $1 \mathrm{t}$ rice straw and $0.2 \mathrm{t}$ rice husk generated. With heat value of straw about 10.9-12.6 MJ/kg and 10.8-12.1 MJ/kg for husk [21], the total potential of rice residue can be estimated at 480-554 PJ per year and 95-106 PJ for straw and husk respectively.

In this study, we explore co-firing technology as a potential pathway to reduce carbon emissions from the fast-growing Vietnamese coal sector. We first assess the economic feasibility of implementing co-firing in Vietnam at national scale and then the potential emission reductions of co-firing technology deployment. To do so, we adapt the BeWhere model [23] in a recursive fashion, to determine a technically optimal scenario for Vietnam based on the biomass availability in the country and different development trajectories of the electricity sector. The results will get insight into the following aspects concerning co-firing practices: which coal plants should do co-firing, how much biomass will be used, what type of biomass, and when should it be implemented. Then, we evaluate the influence of different policies that affect the deployment of co-firing and the associated greenhouse gas emission reductions.

\section{Method: the BeWhere model}

Spatial explicit optimization is a method commonly used to optimize the allocation of resources. This method has been widely used for various types of resources such as solar, wind and especially for optimization of biomass supply chains. A recent study [24] used spatial optimization method to assess the emission reduction from co-firing oil palm biomass with coal in Malaysia. In our study, we select BeWhere - a techno-economic engineering model for renewable energy systems optimization. BeWhere model integrates Geographical Information System (GIS) and Mixed-Integer Linear Programming (MILP) to identify the localization, size and technology of the renewable energy system that should be applied in in a specific region. BeWhere has been used to optimize bioenergy system in regional scale and country scale [2124]. This is the first study using BeWhere for co-firing in Vietnam. We develop the model further as a yearly recursive dynamic model.

Vietnam has a national plan to develop coal power stations describing their locations, capacity and the year when each of them will be operated. Accordingly, we consider the location and size of existing and future coal power plants as exogenous, and only look at the types of cofiring technology that could be deployed, based on their investment costs, resource cost and hypothetical emission reduction benefits. We adopt a recursive dynamic approach and we 
analyze the deployment of co-firing technologies until 2030. These following assumptions have been made:

- Coal power plants are built each year until 2030 as stated in the approved PDP 7A. We assume that the Plan with be implemented as scheduled. Therefore, our aim is not to identify/optimize the location and size of the new plants to be built but to see which plant uses co-firing, and when.

- We assume the absence of any regulation that mandates coal power plants to generate part of their electricity from renewable energy such as the Renewable Standard Portfolio. Power plants' owner decide based on the profitability of co-firing option given an hypothetical internalized carbon cost, instead of an overall emission reduction target set by the government and allocated to each individual plant. Thus, the model represents decentralized decision about co-firing adoption.

- We assume that the input costs and output prices will remain unchanged in the future: long term supply and sales contracts with no risks or revisions. It means once a plant has installed co-firing, its technological and economic conditions are fixed for the rest of its lifetime. Thus, recursive approach is more suitable since it is about taking investment decision as input costs and output prices will not be changed in the future [29].

In our recursive-dynamic approach, optimization is run every year for a set of candidate coal power plants for co-firing. Set of plants for the starting year includes all the existing plants. Results indicate which plant will do co-firing with which technology and at which mixing ratio. In the year $Y$, the set of candidate coal power plants includes the new plants scheduled to open according to the Power Development Plan and the plants in year $Y-1$ that is not switched to cofiring (Equation 1). Biomass resource is distributed among the candidate plants by the optimization. The amount of biomass available in year $Y$ is determined by Equation 2 .

Equation 1

CandidatePlants $_{Y}=$ ProjectedPlants $_{Y}+\left(\right.$ CandidatePlants $_{Y-1}-$ CofirePlants $\left._{Y-1}\right)$

Equation 2

BiomassAvailable $_{Y}=$ BiomassGrowth $_{Y}-$ BiomassConsumed $_{Y-1}$

In this study, we integrate a value of $\mathrm{CO}_{2}$ emissions in the optimization objective to represent policy incitation to co-firing in coal power sector. GAMS's objective (Function 1) is to minimize the production cost of electricity of the system, as in Equation 3, with consideration of avoided cost of emission reduction. Emissions include emission from electricity generation from coal combustion, emission from electricity from co-firing with biomass and emission from biomass transportation (Equation 4).

Function 1

$\min \sum_{\text {sources }}$ Costs + emissions $\times$ social carbon value

Equation 3

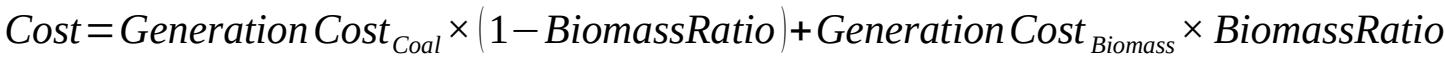

Equation 4

Emission $=$ Emission $_{\text {Coal }}+$ Emission $_{\text {Cofire }}+$ Emission $_{\text {Biomasstransport }}$ 


\section{Data and parameters}

\subsection{Biomass resource}

In this study, we choose two types of raw materials: rice straw and rice husk as these rice residues are the most abundant types of biomass resources in Vietnam [21] and most of them, especially rice straw, is not yet utilized for energy purposes but discarded as waste and usually burned in the fields [24].

Spatial data on rice production in Vietnam in shapefile format is taken from the study of [31]. From this data, information on rice straw and rice husk availability is derived using Residue to Product Ratio (RPR). In this study, RPR of straw is $1: 1$, which means one ton of rice harvested will produce one ton of straw. RPR of husk is $1: 0.2$ [32]. Biomass availability data is disaggregated into a grid of $0.2 \times 0.2$ degree resolution that covered all Vietnam and distributed to grid points where there is cropland for rice (Figure 1). Spatial data on administrative areas and cropland for Vietnam is obtained from [33].
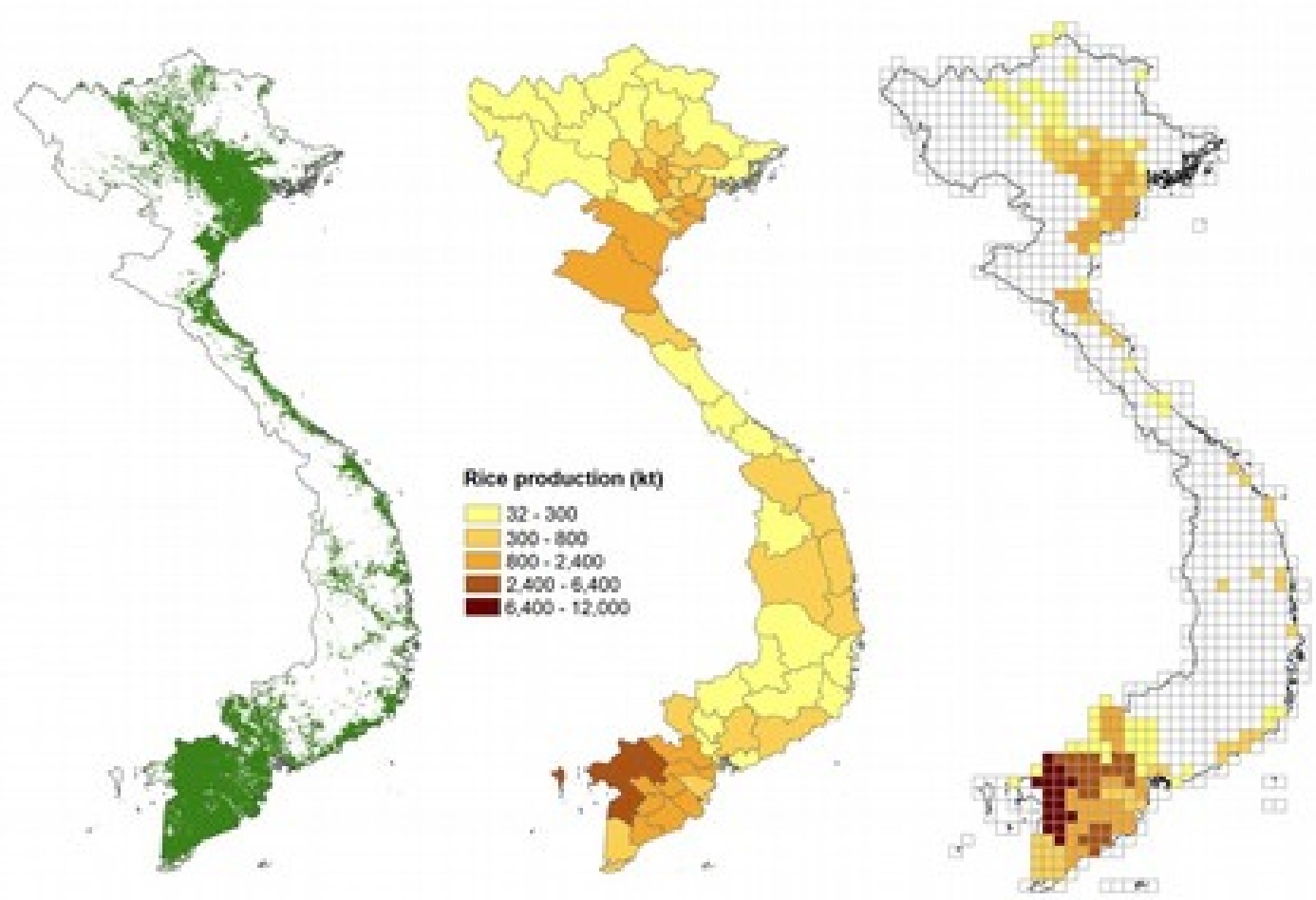

Figure 1. Rice cultivation area (left), rice production by provinces (middle) and discretization of rice production into $0.2 \times 0.2$ degree grid (right).

\subsection{Coal power plants}

The study considers all existing and planned coal-fired utilities listed in the revised National Power Development Plan. Data on coal power plants was extracted from the revised PDP7 dated 18 March 2016 and from GreenID, Vietnam Sustainable Energy Alliance. These data include name, year of operation, capacity and location. Existing coal power plants' efficiencies are taken from [34]. Most of existing coal power plants in used in Vietnam are deploying subcritical Pulverized Coal technology with efficiency range from $28 \%$ to $38 \%$ [31]. For the planned coal power plants, we assume the average efficiency at $38 \%$ and capacity factor of 0.7 . Electricity generation of existing plants is taken from the coal database of GreenID, Vietnam Sustainable Energy Alliance [35]. Location and capacity of coal power utilities are shown in 
Figure 2. Existing coal power plants are mostly located in the Northeast of Vietnam where the largest coal reserves are located. In the future, many more coal power plants are planned in the South to satisfy the demand of the region. These plants are planned near the coast and ports to use imported coal. Recently built and planned coal power plants are switching to Circular Fluidized Bed technology with higher efficiency and more flexibility in terms of fuel used. Cofiring has been demonstrated to work with both coal-fired technologies. There are no plans to deploy the most expensive and efficient technologies such as ultra-supercritical or integrated gasification combined cycle (ICCG).
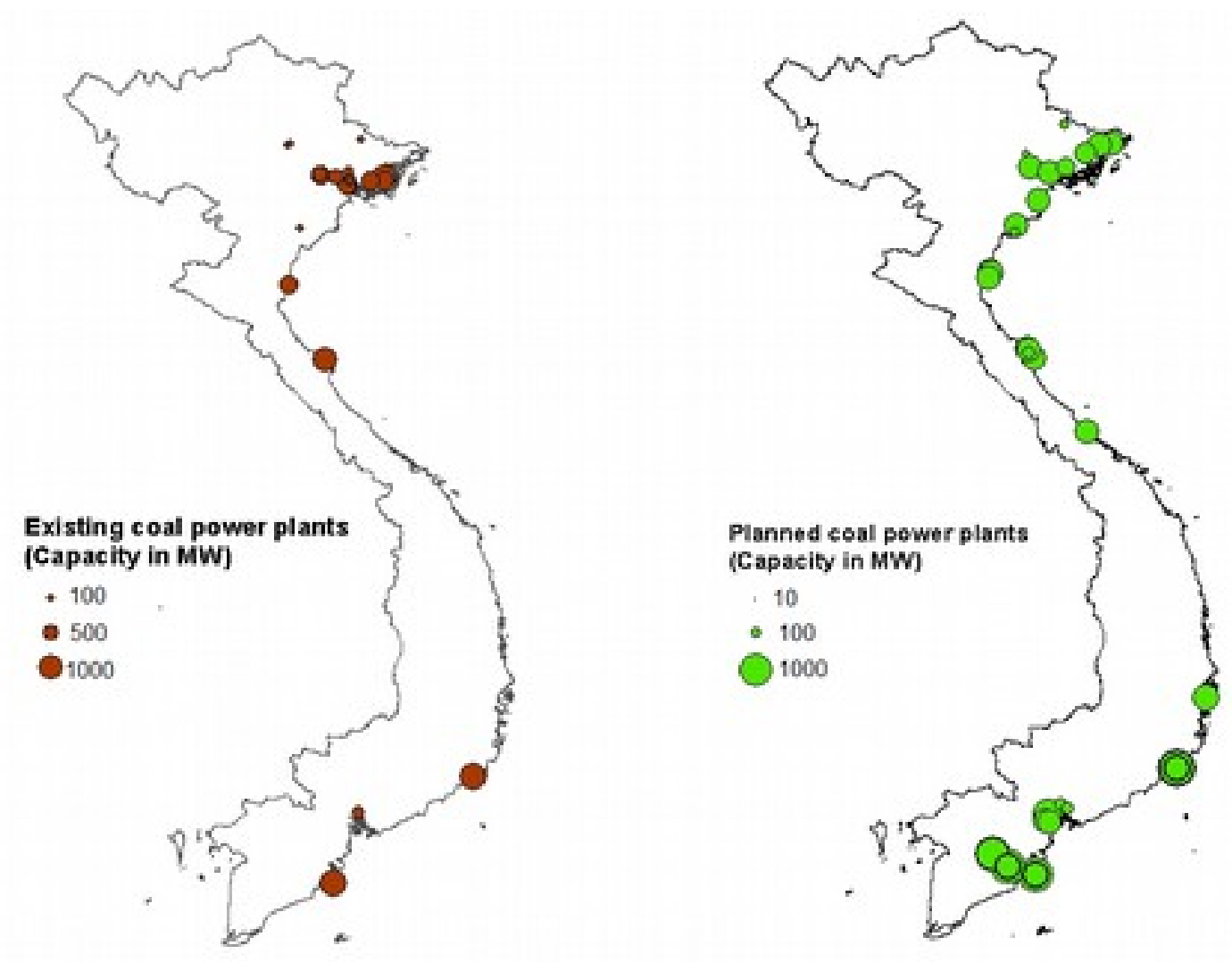

Figure 2. Existing (left) and planned (right) coal power utilities in Vietnam

\subsection{Co-firing technologies}

We consider four existing co-firing technologies with different biomass mixing ratio and cost. These technologies are: (i) direct co-firing using a single boiler, blending biomass together with coal in coal miller; (ii) direct co-firing, milling biomass separately then inject directly to the burner; (iii) indirect co-firing with a gasifier, which converts biomass into synthetic gas (or syngas) that feeds the burner; and (iv) parallel co-firing in which a separate boiler is used for biomass and the generated steam is then mixed with steam from coal boiler [18]. These technologies are both demonstrated in commercial scale or pilot scale. Direct co-firing is the simplest and cheapest option since it does not require major change in coal boiler to adapt to biomass penetration. However, the mixing ratio, percentage of biomass that replace coal on a heat basis, for this technology is 3-5\% [9,18]. With separate injection option, more investment cost is required for new biomass miller, conveyor and injector. Indirect and parallel co-firing require separate gasifier of boiler for biomass, thus increase the investment cost significantly. However, the co-firing rate is much higher compare to direct co-firing technology, up to $20 \%$ according to [18]. 


\subsection{Technical assumptions}

From rice data, we estimate the theoretical potential of rice straw and rice husk in Vietnam at 470 PJ per year and 95 PJ per year, respectively. This estimation is based on the annual rice production of Vietnam, the Residue to Product Ratio (RPR) and heat value of rice straw and rice husk. RPR of straw is $1: 1$ and of husk is $0.2: 1$. Heat value of straw is $11.7 \mathrm{MJ} / \mathrm{kg}$ [36] and of husk is $11.9 \mathrm{MJ} / \mathrm{kg}$ [21].

The technical potential, however, is lower than theoretical. This is because not all residues produced are collected and there are other demands for straw and husk rather than co-firing such as mushroom cultivation or cattle fed. In our study we assume fifty percent of straw and husk produced is available for co-firing.

We also assume that once a coal power plant retrofit for co-firing, they will ensure a long-term biomass supply every year until 2030. Thus, biomass availability for a certain year will exclude the part of biomass that used for co-firing in the previous years.

For our model input, assumptions on investment cost and the upper bound of biomass mixing ratio for each technology can be found in Table 1. Baseline emission factor for coal power plants in taken at $1.056 \mathrm{~kg} / \mathrm{MWh}$ [37].

\subsection{Economic assumptions}

We estimate the cost of producing electricity with pure-coal technology (Equation 5) and cofiring technologies (Equation 6) base on three elements: investment cost, operation and maintenance cost and fuel cost. The investment cost is annualized assuming a discount rate of $7 \%$ and plants' life time of 25 year. The assumptions used to calculate cost of electricity are listed in Table 1.

Equation 5

Generation Cost $_{\text {purecoal }}=C_{I n \nu}+C_{O M}+P_{\text {Coal }} \times Q_{\text {Coal }}$

Equation 6

Generation Cost cofire $=C_{I n v}^{\prime}+C_{O M}^{\prime}+P_{B M} \times Q_{B M}+P_{\text {Coal }} \times Q_{\text {Coal }}^{\prime}$

Where

$C_{I n v}$ is annualized investment cost for coal power plant

$C_{I n v}^{\prime} \quad$ is annualized investment cost of co-firing plant (including investment cost to build the coal power plant and additional cost to retrofit the plant for co-firing)

$C_{O M} \quad$ is operation and maintenance cost of coal power plant

$C_{O M}^{\prime} \quad$ is operation and maintenance cost of co-firing plant

$P_{\text {Coal }}$ is price of coal

$P_{B M} \quad$ is price of biomass

$Q_{\text {Coal }}$ is quantity of coal used in coal power plant

$Q_{\text {Coal }}^{\prime}$ is quantity of coal used in co-firing plant and $Q_{\text {Coal }}-Q_{\text {Coal }}^{\prime}$ is the amount of coal substituted by biomass

$Q_{B M} \quad$ is quantity of biomass used in co-firing plant 
Table 1 Summary of the technical and economic assumptions on the plants for reference scenario

\begin{tabular}{|c|c|c|c|c|c|c|c|}
\hline & \multicolumn{2}{|l|}{ Parameters } & \multicolumn{4}{|c|}{ Co-firing technologies } & \multirow[t]{2}{*}{ Sources } \\
\hline & & $\begin{array}{l}\text { Pure } \\
\text { coal }\end{array}$ & $\begin{array}{l}\text { Direct } \\
\text { fuel } \\
\text { blend }\end{array}$ & $\begin{array}{l}\text { Direct } \\
\text { separate } \\
\text { injection }\end{array}$ & Indirect & Parallel & \\
\hline $\begin{array}{l}\text { Technical } \\
\text { assumptions }\end{array}$ & $\begin{array}{l}\text { Maximum co-firing } \\
\text { rate per technology }\end{array}$ & & $5 \%$ & $15 \%$ & $20 \%$ & $20 \%$ & [18] \\
\hline \multirow[t]{9}{*}{$\begin{array}{l}\text { Economics } \\
\text { assumptions }\end{array}$} & $\begin{array}{l}\text { Investment cost per } \\
\text { technology }\left(\$ / k W_{e}\right)\end{array}$ & 1000 & 51 & 118 & 536 & 1107 & {$[38,39]$} \\
\hline & Coal price $(\$ / G J)$ & & 3.72 & & & & {$[40]$} \\
\hline & Straw price (\$/GJ) & & 3.18 & & & & [36] \\
\hline & Husk price (\$/GJ) & & 1.67 & & & & [21] \\
\hline & $\begin{array}{l}\text { Fix O\&M coal } \\
(\$ / k W / y)\end{array}$ & 29.31 & & & & & [41] \\
\hline & $\begin{array}{l}\text { Variable O\&M coal ( } \$ \text { l } \\
\text { kWh) }\end{array}$ & 0.0048 & & & & & [41] \\
\hline & $\begin{array}{l}\text { Fix OM co-fire }(\$ / \mathrm{kW} / \\
\text { y) }\end{array}$ & & 32.24 & & & & [41] \\
\hline & $\begin{array}{l}\text { Variable OM co-fire } \\
(\$ / k W h)\end{array}$ & & 0.006 & & & & [41] \\
\hline & $\begin{array}{l}\text { Truck Transportation } \\
\text { cost (USD/t/km) }\end{array}$ & & 0.088 & & & & [42] \\
\hline
\end{tabular}

\subsection{Sensitivity Analysis - uncertainty of fuel costs}

Thermal power plants economics are sensitive to fuel costs. To see how fuel cost influences the model's results, we run local sensitivity analysis for eight different scenarios when cost of coal, straw and husk vary by $\pm 10 \%$ of the reference value (see Table 2 ).

We run the model for each cost scenario with different social carbon value ranging from 0 to $30 \mathrm{USD} / \mathrm{tCO}_{2}$ eq with a 1-USD-step to see how the emission reduction curve change under different fuel costs scenarios.

Table 2 Scenarios for sensitivity analysis

\begin{tabular}{llllllllll}
\hline Scenario & $\begin{array}{l}\text { Baseline } \\
\text { case }\end{array}$ & S1 & S2 & S3 & S4 & S5 & S6 & S7 & S8 \\
\hline Coal price & 3.72 & $+10 \%$ & $-10 \%$ & & & & & $+10 \%$ & $-10 \%$ \\
Straw price & 3.18 & & & $+10 \%$ & $-10 \%$ & & $-10 \%$ & $+10 \%$ \\
\hline Husk price & 1.67 & & & & & $+10 \%$ & $-10 \%$ & $-10 \%$ & $+10 \%$ \\
\hline
\end{tabular}




\section{Results}

\subsection{Carbon value and emission reduction}

We simulated scenarios with social carbon value (as used in Function 1) ranging from 1 to $30 \$ / \mathrm{tCO}_{2}$ eq with a 1-USD step. Figure 3 plots the total emission reduction from all coal power plants by 2030 from these 30 social carbon value scenarios. As expected, results show that emission reduction from co-firing increases with social carbon value. The result is a staircase shaped curve, as the model essentially solves from discrete set of investment options: there are four technologies and two types of biomass.

Results show a $4 \mathrm{MtCO}_{2}$ eq at a zero social carbon value. Co-firing appears to be interesting even in the absence of emission reduction incentives.

Under our reference costs and technological performance assumptions, co-firing technology demonstrates its potential of reducing carbon emission from coal power plants in Vietnam. When social carbon value is less than $8 \$ / \mathrm{tCO}_{2} \mathrm{eq}$, the emission reductions obtained by 2030 is only $4 \mathrm{MtCO}_{2}$ eq, about $1.1 \%$ compared to baseline emissions as can be seen in Figure 3.

When carbon value is $8 \$ / \mathrm{tCO}_{2} \mathrm{eq}$, emission reductions reach $27.3 \mathrm{MtCO}_{2} \mathrm{eq}(7.6 \%$ of baseline emission). This jump is explained by the selection of raw material by the system, to be discussed in 4.2 below. From $8 \$ / \mathrm{tCO}_{2} \mathrm{eq}$, the emission reductions plot remains flat. This indicates that increasing carbon value above $8 \$ / \mathrm{tCO}_{2}$ eq does not have much impact to emission reduction. However, higher carbon price still has impact to the selection of co-firing technology by the system as described in 4.3

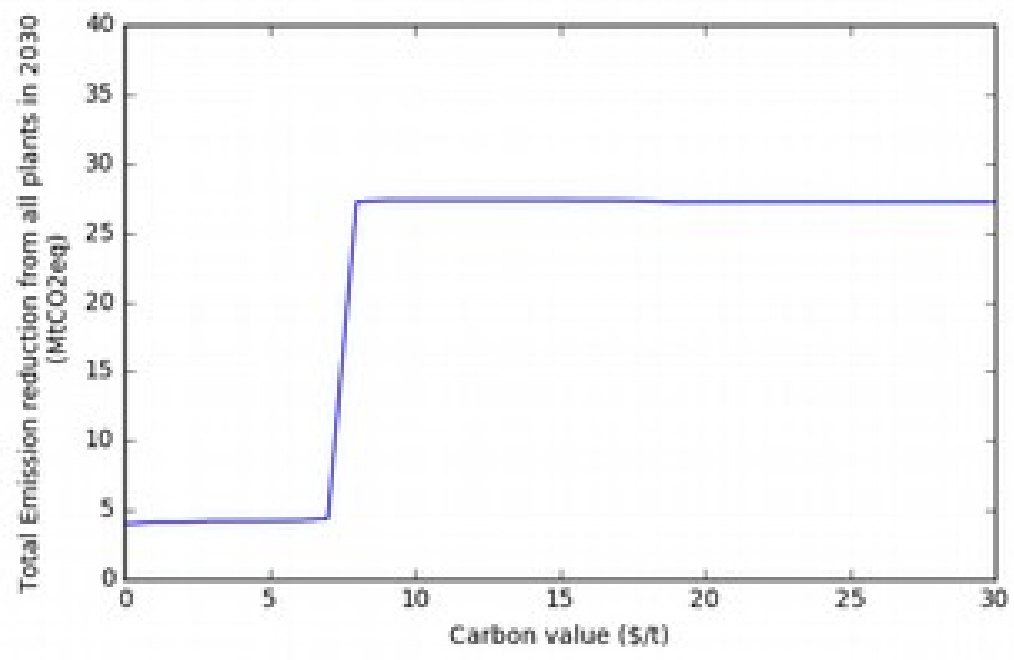

Figure 3 Impact of carbon value to emission reduction from co-firing. The chart shows the emission reduction of all power plants in 2030 when carbon value increase from 0 to $30 \$ / t \mathrm{CO}_{2}$ eq.

\subsection{Biomass utilization}

Figure 4 shows the influences of carbon value on the penetration of biomass in coal power plants in two different carbon value scenarios.

When social carbon value is not accounted (Figure 4 left chart), coal power plants will first select rice husk as co-firing feedstock as its market price is two times cheaper than that of rice straw as shown in Table 1. In the first year, 43 PJ of total 47 PJ technical potential husk is used to generate 14.5 PJ of electricity. The total share of biomass in power generation from coal power plants in Vietnam by 2030 in this case is only $1.2 \%$. 
From 2017 onward, the amount of biomass used for co-firing remains unchanged, meaning no more co-firing capacity is added. This is because without any incentive, it is not profitable for the plants to co-firing using rice straw, a feedstock that is twice more expensive than husk.

Co-firing with straw becomes competitive and used by the power plants when carbon value is at $8 \$ / \mathrm{tCO} 2$ eq (Figure 4 , right chart). At this level of subsidy, co-firing can contribute to a $7.6 \%$ share to power generation by 2030 using 256 PJ of biomass. With higher availability than husk, rice straw can provide biomass for more plant to deployed co-firing in later years. The amount of straw co-fired by the system grows over years since new plants can only use straw for co-firing when husk is used up. However, rice residue is not sufficient for all power plants to do co-firing. This can be seen from Figure 5. When carbon value is $8 \$ / \mathrm{tCO} 2 \mathrm{eq}$, biomass is used up by 2020 resulted in a flat line from this year onward. When carbon value is as high as $20 \$ / \mathrm{tCO}$ eq, rice residue run out even earlier in 2019 as more biomass is mobilized in the first year when higher biomass mixing ratio technology is deployed (as described in section 4.3).
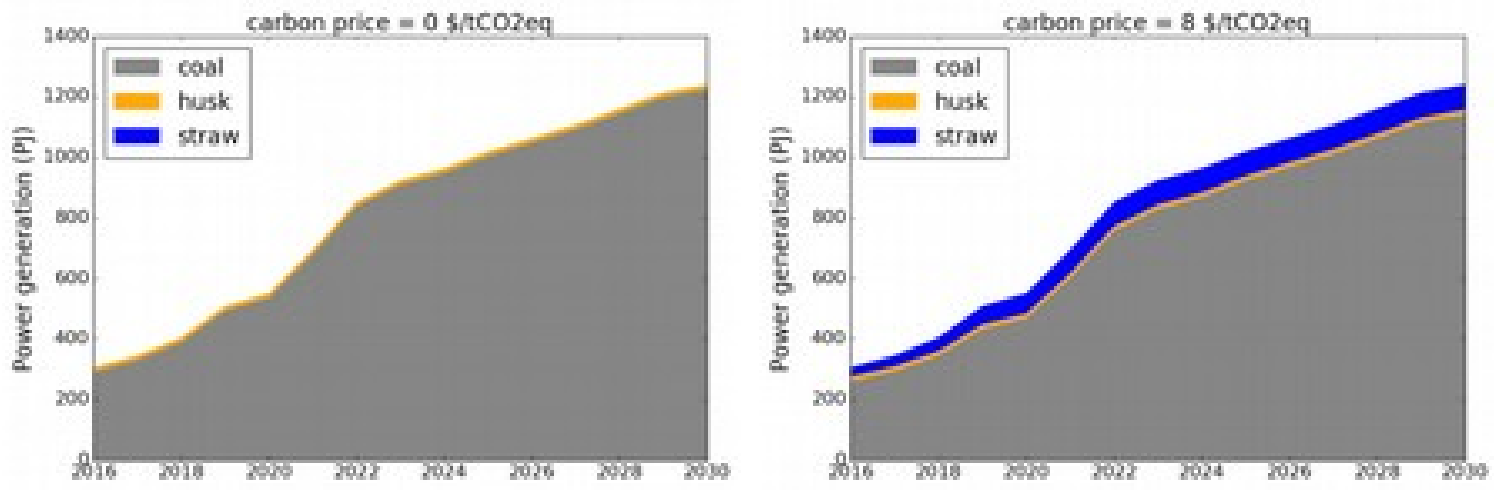

Figure 4. Share of rice residue in power generation from coal power plants at different carbon value: $0 \$ / t C \mathrm{O}_{2} e q$ (left), $8 \$ / t \mathrm{CO}_{2} e q($ right)

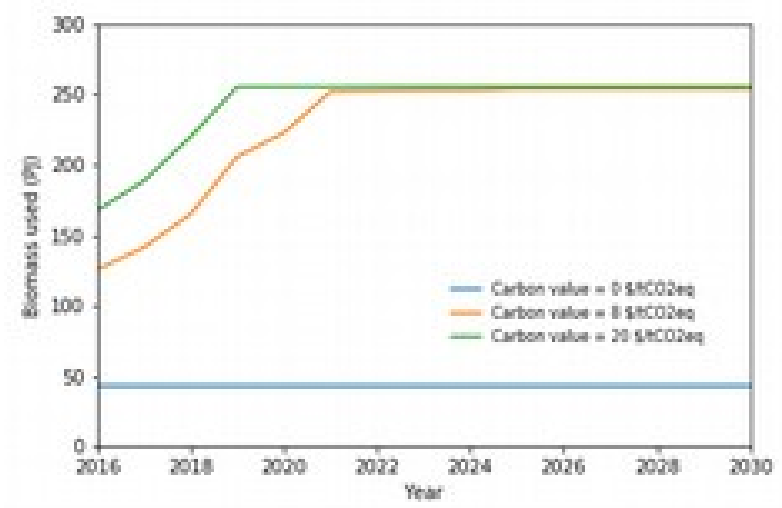

Figure 5. Biomass utilization in different carbon value scenario 


\subsection{Technology deployment}

Two out of four co-firing technologies are selected: direct co-firing with separate biomass injection and indirect co-firing Figure 6. Although direct co-firing with fuel blend has lower investment rate than direct co-firing with separate injection, the coal substitution percentage is much lower. Thus, the power generation cost of fuel blend technology is slightly higher than that of separate injection technology. As shown in the left chart of Figure 3, the increase in carbon value higher than $8 \$ / \mathrm{tCO}_{2}$ eq does not change the total emission reduction of the system. However, the configuration of co-firing technology of the system does change with the increase of social carbon value.

When there is no carbon value, separate injection technology is selected to co-fire rice husk. There is not enough rice husk produced in Vietnam for co-firing in all existing coal power plants, only 14 out of 28 existing plant can do co-firing in the first year and no more co-firing capacity added in the following years (Figure 6a). This is also the same situation for the system when carbon value is lower than $8 \$ / \mathrm{tCO}_{2}$ eq.

When carbon value is at $8 \$ / \mathrm{tCO}_{2} \mathrm{eq}$, all coal power utilities deploy direct co-firing technology with separate injection until year 2020 (Figure 6b), at which point no more plant is able to cofire with straw and husk because of resource depletion and the coal plants added after 2020 still run on coal only. After this year, the system keeps the configuration of co-firing with direct separate injection technology with the same biomass mixing ratio when carbon value varies from 8 to $15 \$ / \mathrm{tCO}_{2}$ eq.

Since indirect co-firing is a more expensive technology than direct co-firing, it is only deployed when carbon value exceed the thread hold of $16 \$ / \mathrm{tCO}_{2}$ eq (Figure 6c). However, only one plant uses indirect co-firing in this carbon value scenario. The number of plant using indirect co-firing technology increases with carbon value until the carbon value reaches $20 \$ / \mathrm{tCO}_{2}$ eq (Figure 6d). Because the technology allows plants to co-fire at $20 \%$, more straw and husk are utilized at the beginning. This results in rice residue resource depletion in 2019, a year earlier than in the scenarios where direct co-firing with separation injection technology is mostly used. 


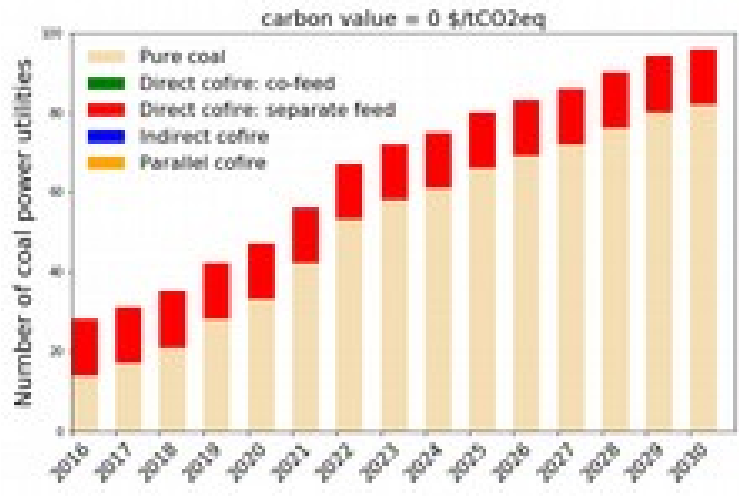

(a)

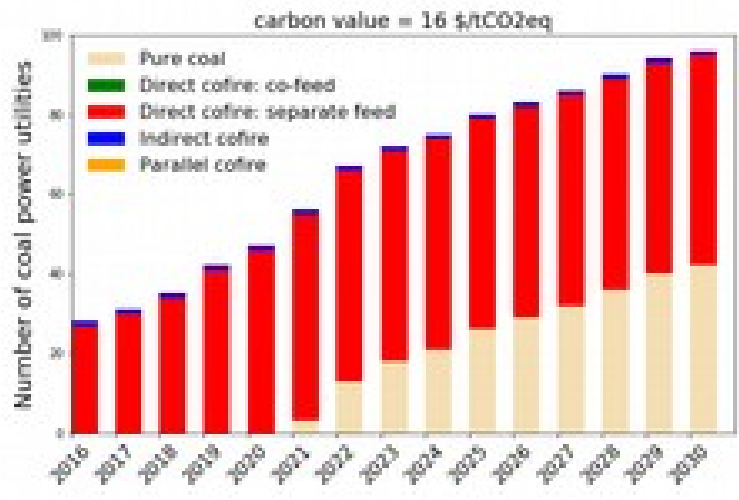

(c)

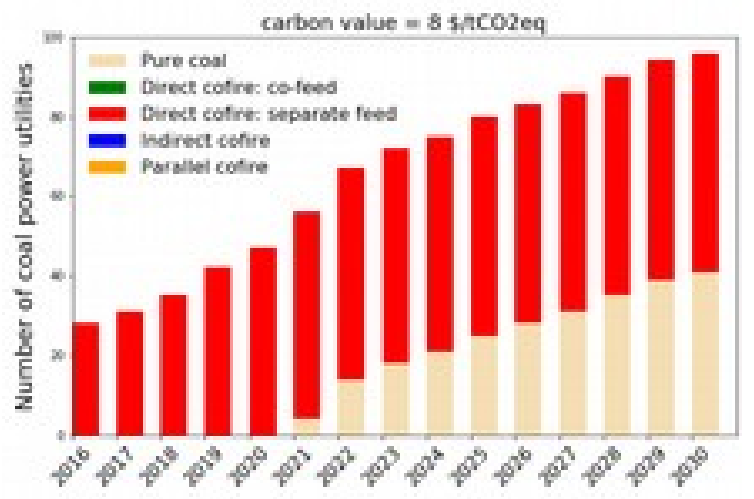

(b)

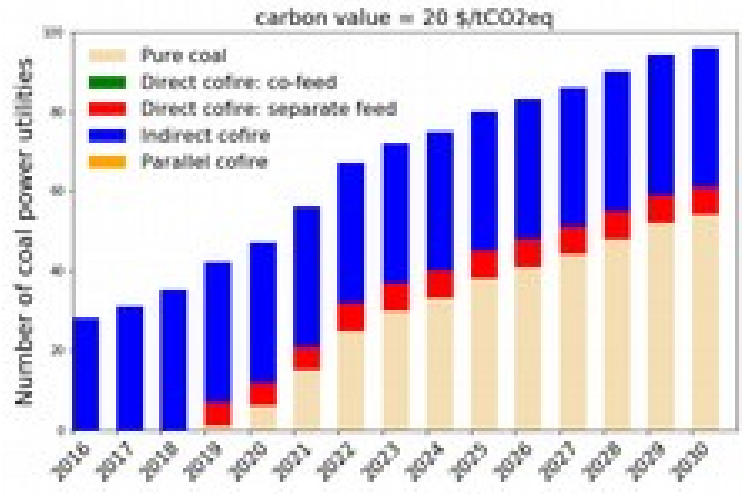

(d)

Figure 6. Co-firing technology deployment at different carbon value.

\subsection{Sensitivity analysis}

Results of sensitivity analysis are presented in four charts in Figure 7 with different scenarios plotted with baseline case to see how the changes in different fuel impact the deployment of cofiring technology. For example, Figure $7 \mathrm{~d}$ shows emission reduction curve (similar curve as in Figure 3) of baseline scenario in comparison to the emission reduction curves in S1 and S2 scenario where husk price increased and decreased by $10 \%$ respectively. Figure $7 \mathrm{c}$ shows the emission reduction curve when straw price varies. Figure $7 \mathrm{~b}$ shows emission reduction curves for coal price sensitivity analysis and Figure 7a compares baseline scenario with "best case" scenario for co-firing, where coal price increased by $10 \%$ and straw and husk price both decreased by $10 \%$, and "worst case" scenario where coal price decreased by $10 \%$ and biomass price increased by $10 \%$. The results of sensitivity analysis (Figure 7 ) of fuel price (coal price, straw price and husk price) show that the co-firing system is sensitive to fuel price. However, the sensitivities vary from fuel to fuel.

Result shows that the system is least sensitive to husk price as the 3 lines ovelapped in Figure $7 \mathrm{~d}$. This is because husk price is about two times lower than straw and coal, thus the cost to purchase husk for co-firing is accounted for much smaller part in total fuel cost of coal power plants. Moreover, rice husk availability can only satisfy a small portion of electricity production (Figure 4, left chart). Thus, the impact of husk price change is much less important than changes in coal price or straw price.

The system has the same sensitivity to coal price and straw price. Straw price lowered by $10 \%$ (S4) and coal price increased by $10 \%$ (S1) can shift the emission reduction line to the left, 
which means it can help the system to reach the same level of emission reduction as in baseline case at lower carbon value. In these scenarios, carbon value to reach maximum emission reduction is about $4 \$$ lower than baseline case. On the other hand, straw price increased by $10 \%$ or coal price decreased by $10 \%$ both shift the emission reduction line to the right where higher carbon value is needed to reach the same emission reductions.

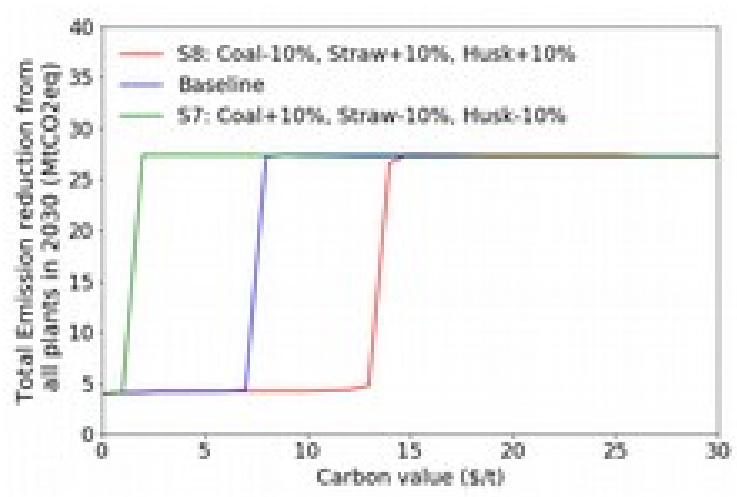

(a)

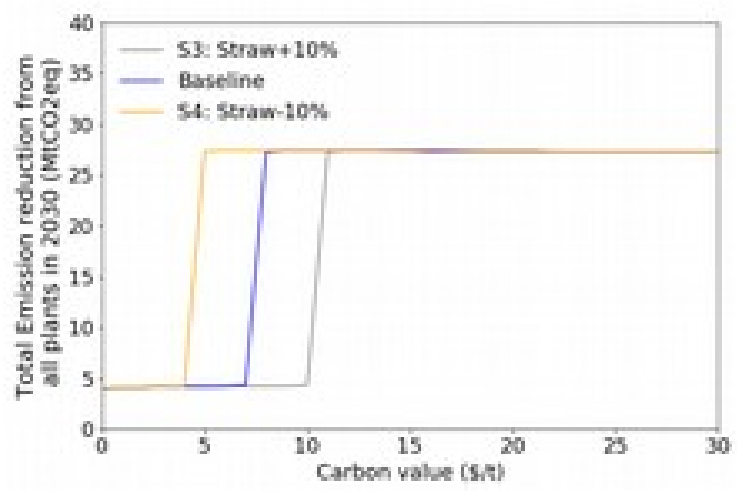

(c)

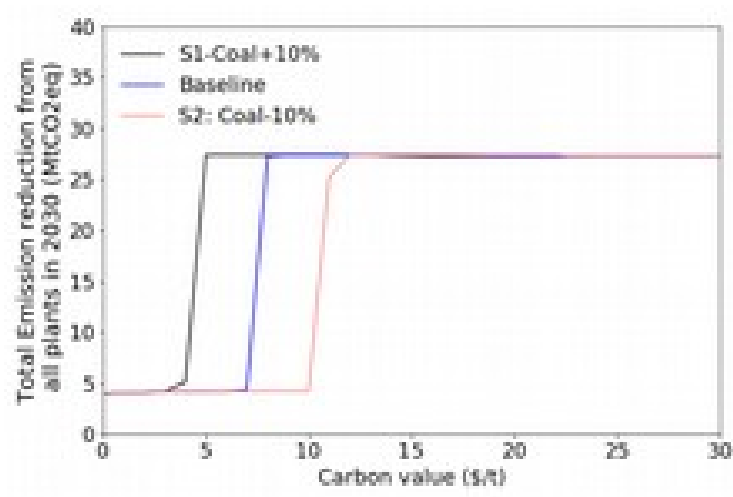

(b)

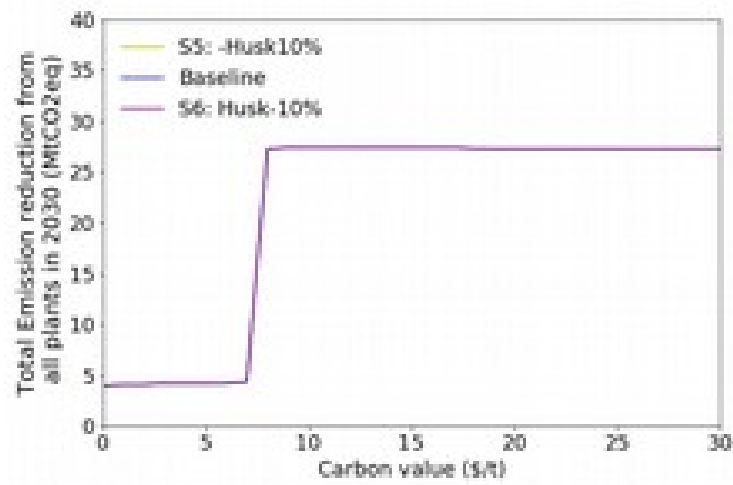

(d)

Figure 7. Sensitivity analysis of fuel costs impact to emission reduction. The three lines are overlapped in Figure $7 d$.

\section{Discussion}

We found that even without carbon value incentive, co-firing with rice husk is cheaper than using coal in coal power plants. The total cost of electricity generation of the system is reduced by $36 \mathrm{M} \$$ compared to the baseline total cost of $20389 \mathrm{M} \$$ when co-firing husk. This is a $0.2 \%$ savings, which may not be enough to trigger industrial investment in a technology never used before in the country. The barrier is not only financial risk. Inadequate market structures and contracts issues alone can prevent a technology like co-firing to arise.

The limited rice husk resource can only afford co-firing in 14 plants out of total 96 coal power plants at a $15 \%$ mixing ratio. In this case, the amount of emission reduced is only $1.1 \%$ compared to baseline emission of coal power plants without co-firing. We interpret that without incentives, co-firing can be considered as a way to valorize rice residue, but is not likely to lead to large greenhouse gas emission reduction from coal power plants in Vietnam.

We found that with incentives, co-firing could have a significant role in reducing greenhouse gas emissions from coal-based power stations, up to $7.6 \%$ below baseline. This finding corroborates with the lessons from international experience: in all other countries, co-firing needed incentives to be deployed. 
In our study, Vietnam coal sector can achieve $8 \%$ emission reduction already with a carbon value at $8 \$ / \mathrm{tCO}_{2}$ eq. Emission reductions remain at this level even when carbon value is as high as $30 \$ / \mathrm{tCO}_{2}$ eq. When comparing the price of carbon with the emission reduction it can deliver, we found that carbon value at $8 \$ / \mathrm{tCO}_{2} \mathrm{eq}$ is the most interesting cost-effective. In this scenario, the total additional cost of the system for co-firing is $137 \mathrm{M} \$$.

When carbon price is at $20 \$ / \mathrm{tCO}_{2} \mathrm{eq}$, most of the plants switch from direct to indirect co-firing. However, the total emission reduction is at the same level as when all co-firing plants deploy direct technology. The interpretation of that result is that indirect co-firing technologies are not competitive. Among the two co-firing technologies selected by the system, direct co-firing with separate injection offers a good compromise between mixing ratio and economic efficiency. This allows the technology to be deployed at moderate carbon value $\left(8 \$ / \mathrm{tCO}_{2} \mathrm{eq}\right)$. Indirect cofiring allows higher mixing ratio but required large amount of subsidy to be utilized. The additional cost for producing electricity of the system in case indirect co-firing is deployed is $206 \mathrm{M}$ \$. For the short and medium-term, direct co-firing is the better option for coal power plants in Vietnam when they want to generate part of their power production from renewable resources.

To complement the techno-economic analysis conducted so far, we offer a few remarks about opportunities and barriers for co-firing in Vietnam from macro-economic point of view.

First the recursive-dynamic model predicts that only rice residues are not enough for all coal power plants in Vietnam to co-fire at high biomass percentage. This is shown in Figure 4 for carbon value at $8 \$ / \mathrm{tCO}_{2}$, in which from 2021 rice residue is not enough for all plants to co-fire at $15 \%$. This limit can be relaxed if we consider international trade, or other biomass types for co-firing such as forest residue or biomass pellets. There is an active international market in biomass pellet for energy. Vietnam has production capacities and exported to South Korea and Japan, for example, with 2.5 million metric ton exported in 2017 [43].

Second, carbon value and biomass price interact to influence the choice of raw materials and cofiring technology. If raw materials are cheaper, then less incentive are needed for co-firing to be applied. Conversely, the emission reduction curve shifts to higher carbon price when biomass becomes more expensive. Markets are dynamic and uncertain, but there is a known pattern: when a biomass waste is valorized, it becomes a resource, and its price increases according to the law of offer and demand. For example in 2016 we observed that the demand for rice husk in Thailand market led to increases in price in the neighboring country of Cambodia [44].

Third, sensitivity analysis shows that the adoption of co-firing is sensitive to coal price. Coal price in Vietnam for electricity generation is controlled by the government, who also regulates electricity retail price. Keeping both the price of input (coal) and output (electricity) low allows serving affordable electricity to the population, while controlling the debt level of the utilities. However, this low prices policy can be seen as a barrier to the adoption of renewable electricity technologies including co-firing.

Fourth, while our model uses a carbon value to internalize the climate policy constraints, incentives are not limited to price instruments. International experience shows that a renewable portfolio standard, which prescribes power generation companies to provide a fraction of green electricity in their mix, can lead to the adoption of co-firing.

Fifth, agricultural residues are a domestic resource and contribute to the energy security of supply. The latest Coal Development Plan approved by the Prime Minister predicts that coal demand for electricity generation will increase from $33 \mathrm{Mt}$ in 2016 to $64 \mathrm{Mt}$ in 2020 and to $131 \mathrm{Mt}$ in 2030 [45]. Supply side, the total coal production of the country is planned to grow to $57 \mathrm{Mt}$ in 2030. We doubt that this will much be produced, since recent past statistics rather show that Vietnam passed peak coal already. In any case, many coal power plants will rely on imported coal. The 2030 plan is to import more than $75 \mathrm{Mt}$ of coal, about $60 \%$ of coal demand 
for power plants. This will make the national economy more sensitive to international coal price variation. Co-firing would help to mitigate the vulnerability to international coal markets.

It should be noted that some issues might occur when blending biomass with coal in co-firing applications such as explosion risk from biomass storage, low grindability of biomass, fouling and corrosion of boilers $[10,14,46]$. Most of the technical issues result from the differences in combustion properties of coal and biomass, thus the performance of co-firing plants is largely affected by the type of feedstock adopted in the combustion process. For instance, rice residues are much more problematic to co-fire than conventional wood in term of grindability and fouling.

Co-firing thresholds that are considered in this study $(5 \%, 15 \%, 20 \%$ and $20 \%$ coal replaced by biomass in term of heat for direct co-firing with fuel blend, direct co-firing with separate injection, indiect and parallel co-firing, respectively) should also be checked on a case-by-case basis, by performing detailed analysis of the fuel compositions, and/or pilot and full-scale testing.

\section{Conclusion}

We explored the potential of co-firing rice residues in coal power plants to reduce greenhouse emission reduction in Vietnam as one approach to tackle energy trilemma in Vietnam. The BeWhere model produced a marginal abatement cost curve which has two domains.

A/ At low carbon values, co-firing with rice husk blend in the grinder can profitably be used. This leads to a $1.1 \%$ sectoral emission reduction.

$\mathrm{B} / \mathrm{At}$ higher carbon values, rice straw is used in addition to husk. We estimate the economic potential to a $8 \%$ sectoral emissions reduction. Increasing the carbon value above further does not bring more co-firing capacity online, because the rice residue resource is limited.

The critical carbon value where rice straws is used is $8 \$ / \mathrm{tCO}_{2}$ eq in the central case. It depends on the prices of coal and straw. This carbon value may look high in a domestic policy context given that Vietnam is a lower middle-income country. However, it may be worth a look in the context of an international company seeking to reduce its global emissions.

Achieving ambitious national emission reduction policy targets $-25 \%$ below baseline with international support by 2030 - requires a portfolio of measures. In the power generation sector, besides demand management, measures include using other energy sources such as natural gas, wind and solar radiation to avoid building new coal power plants. But given the current trends, coal is to remain a major energy source in Vietnam in 2030. Mitigation policies will also include measures like increasing plants' thermal efficiency, biomass co-firing, and possibly negative emission technologies such as carbon capture and sequestration. In this portfolio of measures, co-firing has the potential to contribute a significant part to the emission reduction effort of Vietnam: a $8 \%$ reduction of the largest emission sector. With the difficulty that cofiring might fall under a global policy ban on anything coal-related, the technology is mature and appropriate to the development level of the country. Co-firing can utilize the existing infrastructure of coal power plants and domestic biomass resources. This is not a silver bullet, but an interestingly low-hanging fruit.

\section{Acknowledgement}

Part of the research was developed in the Young Scientists Summer Program at the International Institute for Applied Systems Analysis, Laxenburg (Austria) with financial support from the Vietnam National Member Organization.

This research did not receive any specific grant from funding agencies in the public, commercial, or not-for-profit sectors. 


\section{References}

[1] World Energy Council. World Energy Issues Monitor 2017. World Energy Council; 2017.

[2] MONRE. Intended Nationally Determined Contribution of Vietnam. n.d.

[3] VNEEP. Energy Statistics Vietnam 2015. Hanoi: National Energy Efficiency Program; 2016.

[4] EVN. Vietnam electricity annual report 2016. EVN; 2017.

[5] The Government of Vietnam. The adjustments of 7th Vietnam Power Development Planning 2016.

[6] MONRE. The initial biennal updated report of Viet Nam to the UNFCCC. Ha Noi, Viet Nam: 2014.

[7] Nguyen TTH, Doan ND, Nguyen CT, Trinh HL, Vu TU, Le NV, et al. Determination of GHG control measures in coal power sector and proposed implementation pathway 2015.

[8] World Energy Council. Policies for the Future, 2011 Assessment of Country Energy and Climate Policies. 2011.

[9] Agbor E, Zhang X, Kumar A. A review of biomass co-firing in North America. Renew Sustain Energy Rev 2014;40:930-43. doi:10.1016/j.rser.2014.07.195.

[10] Sahu SG, Chakraborty N, Sarkar P. Coal-biomass co-combustion: An overview. Renew Sustain Energy Rev 2014;39:575-86. doi:10.1016/j.rser.2014.07.106.

[11] Andrić I, Jamali-Zghal N, Santarelli M, Lacarrière B, Le Corre O. Environmental performance assessment of retrofitting existing coal fired power plants to co-firing with biomass: carbon footprint and emergy approach. J Clean Prod 2015;103:13-27. doi:10.1016/j.jclepro.2014.08.019.

[12] Morrison B, Golden JS. Life cycle assessment of co-firing coal and wood pellets in the Southeastern United States. J Clean Prod 2017;150:188-96. doi:10.1016/j.jclepro.2017.03.026.

[13] Dzikuć M, Piwowar A. Ecological and economic aspects of electric energy production using the biomass co-firing method: The case of Poland. Renew Sustain Energy Rev 2016;55:856-62. doi:10.1016/j.rser.2015.11.027.

[14] Roni MS, Chowdhury S, Mamun S, Marufuzzaman M, Lein W, Johnson S. Biomass cofiring technology with policies, challenges, and opportunities: A global review. Renew Sustain Energy Rev 2017;78:1089-101. doi:10.1016/j.rser.2017.05.023.

[15] Hansson J, Berndes G, Johnsson F, Kjärstad J. Co-firing biomass with coal for electricity generation-An assessment of the potential in EU27. Energy Policy 2009;37:1444-55. doi:10.1016/j.enpol.2008.12.007.

[16] IRENA. Biomass for Power Generation. International Renewable Energy Agency (IRENA); 2012.

[17] International Energy Agency. Biomass for Power Generation and CHP. International Energy Agency; 2007.

[18] IRENA. Biomass Co-firing-Technology Brief. IRENA and IEA-ETSAP; 2013.

[19] Nguyen CT, Hoang TD. Study on co-firing domestic coal with imported coal to improve the fuel utilization efficiency in coal power plants in Vietnam. Inst Energy 2016. http://www.ievn.com.vn/UserFile/Files/News/2016/Thang\%20TT3/C\%C3\%B4ng\%20ngh $\%$ E1\%BB\%87\%20\%C4\%91\%E1\%BB\%91t\%20than/Baibao-\%20Bo\%20Cong $\% 20$ Thuong.pdf.

[20] Tsalidis G-A, Joshi Y, Korevaar G, de Jong W. Life cycle assessment of direct co-firing of torrefied and/or pelletised woody biomass with coal in The Netherlands. J Clean Prod 2014;81:168-77. doi:10.1016/j.jclepro.2014.06.049.

[21] Arvo L, Nguyen DC. Development of biomass fuel chains in Vietnam. Technical Research Centre of Finland; 2013.

[22] General Statistics Office Of Vietnam. Statistical Handbook of Vietnam 2016. Hanoi, Vietnam: Statistical Publishing House; 2017. 
[23] BeWhere - BEWHERE - IIASA n.d.

http://www.iiasa.ac.at/web/home/research/researchPrograms/EcosystemsServicesandMana gement/BEWHERE/BEWHERE.en.html (accessed September 29, 2017).

[24] Nurariffudin M, Hashim H, Razak NH. Spatial optimisation of oil palm biomass co-firing for emissions reduction in coal-fired power plant. J Clean Prod 2017. doi:10.1016/j.jclepro.2017.11.027.

[25] Wetterlund E, Leduc S, Dotzauer E, Kindermann G. Optimal localisation of biofuel production on a European scale. Energy 2012;41:462-72. doi:10.1016/j.energy.2012.02.051.

[26] Patrizio P, Leduc S, Chinese D, Kraxner F. Internalizing the external costs of biogas supply chains in the Italian energy sector. Energy 2017;125:85-96. doi:10.1016/j.energy.2017.01.033.

[27] Khatiwada D, Leduc S, Silveira S, McCallum I. Optimizing ethanol and bioelectricity production in sugarcane biorefineries in Brazil. Renew Energy 2016;85:371-86. doi:10.1016/j.renene.2015.06.009.

[28] Patrizio P, Leduc S, Chinese D, Dotzauer E, Kraxner F. Biomethane as transport fuel - A comparison with other biogas utilization pathways in northern Italy. Appl Energy 2015;157:25-34. doi:10.1016/j.apenergy.2015.07.074.

[29] Babiker M, Gurgel A, Paltsev S, Reilly J. Forward-looking versus recursive-dynamic modeling in climate policy analysis: A comparison. Econ Model 2009;26:1341-54. doi:10.1016/j.econmod.2009.06.009.

[30] Nguyen MD. Estimation of air pollutant emission from rice straw combustion in the open air in Red River Delta. J Sci Dev 2012;10:190-8.

[31] Laborte AG, Gutierrez MA, Balanza JG, Saito K, Zwart SJ, Boschetti M, et al. RiceAtlas, a spatial database of global rice calendars and production. Sci Data 2017;4:170074. doi:10.1038/sdata.2017.74.

[32] Nguyen DC. Identification of biomass market opportunities in Vietnam. Deutsche Gesellschaft für Internationale Zusammenarbeit (GIZ) GmbH; 2011.

[33] Free Spatial Data|DIVA-GIS n.d. http://www.diva-gis.org/Data (accessed March 19, 2018).

[34] Institute of Energy-MOIT. Development of greenhouse gas control measures in coal-fired thermal power and proposed schedule to apply these measures. Ministry of Indutry and Trade; 2014.

[35] GreenID. Coal Power Plant Database. Vietnam Sustainable Energy Alliance; 2017.

[36] Truong AH. Feasibility and sustainability of co-firing biomass in coal power plants in Vietnam. Master of Science Thesis. University of Science and Technology of Hanoi, 2015.

[37] Finenko A, Thomson E. Future Carbon Dioxide Emissions from Vietnam's Coal Power Generation Sector. Energy Procedia 2014;61:1519-23. doi:doi:10.1016/j.egypro.2014.12.160.

[38] Lüschen A, Madlener R. Economic viability of biomass cofiring in new hard-coal power plants in Germany. Biomass Bioenergy 2013;57:33-47. doi:10.1016/j.biombioe.2012.11.017.

[39] Ministry of Construction. Decision no.706/QĐ-BXD 2017 on publishing Investment rate of constructions. vol. 706/QĐ-BXD. 2017.

[40] Ministry of Industry and Trade, General Directorate for Energy. Transparency in Electricty and Petrol business 2018. http://minhbach.moit.gov.vn/? page $=$ electricity_define\&key=electricity_thongso\&menu_id=72 (accessed March 10 , 2018).

[41] Broadman R, Bearden M, Cafferty K, Cabe J, (first). Logistics, Costs, and GHG Impacts of Utility-Scale Cofiring with $20 \%$ Biomass. Idaho National Laboratory and Pacific Northwest National Laboratory; 2013. 
[42] Van Tai Duong Viet. Transportation price for truck. Van Tai Duong Viet n.d. http:/vantaiduongviet.com/thuexetai/chothuexetai/giachothuexetai/tabid/444523/ language/vi-VN/Default.aspx (accessed December 5, 2016).

[43] Strauss W. Vietnam Wood Pellet Exports Rapid growth and low prices. Can it last? What is the Future? n.d.:8.

[44] Nguyen HN, Ha-Duong M, Van de Steene L. A critical look at rice husk gasification in Cambodia: technology and sustainability. Vietnam Acad Sci Technol 2015;53:247-51.

[45] Prime Minister. Approval of revised Master plan for Coal sector development in Vietnam to 2020 with vision to 2030. 2016.

[46] Basu P, Butler J, Leon MA. Biomass co-firing options on the emission reduction and electricity generation costs in coal-fired power plants. Renew Energy 2011;36:282-8. doi:10.1016/j.renene.2010.06.039. 